\title{
Articles with authors affiliated to Brazilian institutions published from 1994 to 2003 with 100 or more citations: I - The weight of international collaboration and the role of the networks
}

\author{
ABEL L. PACKER and ROGERIO MENEGHINI
}

\author{
BIREME/PAHO/WHO - Latin American and Caribbean Center on Health Sciences Information / \\ Pan American Health Organization / World Health Organization, \\ Rua Botucatu 862, 04023-901 São Paulo, SP, Brasil \\ UNIFESP - Universidade Federal de São Paulo, Departamento de Informática em Saúde - DIS \\ Rua Botucatu 862, 04023-901 São Paulo, SP, Brasil
}

Manuscript received on May 2, 2006; accepted for publication on May 31, 2006; contributed by ROGERIO MENEGHINI*

\begin{abstract}
Articles with 100 citations or more in the scientific literature and with at least one author with Brazilian affiliation, were identified in the Thomson-ISI (Institute for Scientific Information) Web of Science bibliometric database, covering a 10-year period, from 1994 to 2003; $248(0.23 \%)$ out of a total of 109,916 articles with Brazilian affiliation were identified. This study was primarily carried out to identify thematic nuclei of excellence in research that had major impact in the international literature (Meneghini and Packer 2006). The regional and institutional affiliation distributions of these articles follow approximately that of the total of Brazilian articles in the ISI database. However, some significant deviations are observed derived from the outstanding performance of a few groups responsible for the publication of the HC-ISI (Highly cited ISI) papers. The international collaboration and the network organization of work played a fundamental role in these results. It is evident that the role played by organizations in research networks as well as the international collaborations exerted strong influence in the impact of these articles, although with distinct amplitude in the different fields.
\end{abstract}

Key words: bibliometry, editing/statistics and numerical data, information service, storage and retrieval information, science, authorship, journals/rules, scientometrics, impact factor, scientific collaboration, scientific network.

\section{INTRODUCTION}

The impact of a scientific article can be directly measured by the number of times it is cited after publication (Garfield and Small 1978). Although there is much discussion about why an article is cited, there is a significant correlation between the quality and

* Member Academia Brasileira de Ciências Correspondence to: Rogerio Meneghini

E-mail: rogmeneg@bireme.br relevance of an article and the number of citations it generates (Garfield and Welljams-Dorof 1992).

The most widely used database for measuring citations is the Web of Science Thomson-ISI (Institute for Scientific Information), which indexes over 8000 journals on natural sciences, social sciences and arts (http://isiwebofknowledge.com). This paper is based on these two paradigmatic pillars: citation and quality. Despite there being room 
for advancement and improvement in the area of scientometrics and "citationology", the correlation citation-quality is well documented in a series of articles (see Meneghini and Packer 2006).

The ability to judge the scientific standard of a nation is vital for governments and for the productive sector to enable decisions on scientific and funding priorities. In a recently published article (King 2004), David King, a major consultant for scientific and technological affairs of the British government, analyzed the outcomes of investment in research to measure quality at a national level and to compare it with the international scenario. To this end, the author chose the number of citations of articles, instead of the number of publications as is normally the case because he considered the former reflects quality better than the latter. As a benchmark, King took the $1 \%$ top tier of articles with the highest citation index in the period 1993-2002 for 31 countries, encompassing 98\% of the most-cited articles within this sample. Brazil is among these countries.

\section{METHODOLOGICAL APPROACH}

The present study adopted a similar methodological approach exclusively for Brazil for the period 19942003. The articles with over 100 citations were identified in the Thomson ISI database for the period mentioned. The data were collected in the base in April 2005. The major objective was to identify fields of excellence in different scientific disciplines, their genesis and repercussion. As collateral products of our survey, institutions and groups responsible for such excellence could be detected, as well as the importance of a multinational collaboration process and the effect of working within large networks, which are all very valuable.

The results should be considered within their limits, since we have not carried out normalization as to the year of publication or the field of knowledge. Therefore, an article published in 2003 that has 100 citations should be considered as having greater impact than one published in 1994 and cited the same number of times, since the former achieved this rate in a shorter timeframe. However, since it was not our intent to carry out a temporal development analysis as King did (King 2004), normalization for the year of publication was not important. However, the normalization for citation trends in different disciplines, which was not carried out due to data unavailability, may have impaired the identification of excellence in certain areas as will be discussed later.

The results obtained show important aspects of Brazilian science in this recent period which may be of great interest for national research and technology policies.

\section{DISTRIBUTION OF ARTICLES WITH MORE THAN 100 CITATIONS}

Through the webofscience, Thomson ISI, we identified 248 articles with more than 100 citations among 109,916 articles with Brazilian affiliation and published in the period 1994-2003. Therefore we dealt with $0.23 \%$ of the total publications regarding the most-cited articles. These articles were classified in eight fields as shown in Table I.

TABLE I

Most-cited articles in the 1994-2003 period, per field.

\begin{tabular}{l|c}
\hline \multicolumn{1}{c|}{ Field } & $\begin{array}{c}\text { Number of articles } \\
\text { with over } \\
100 \text { citations }\end{array}$ \\
\hline Biomedicine & 67 \\
\hline Medicine & 51 \\
\hline Physics & 41 \\
\hline Biology & 29 \\
\hline Chemistry & 23 \\
\hline Astronomy & 17 \\
\hline Surgery & 17 \\
\hline Engineering & 3 \\
\hline Total & $\mathbf{2 4 8}$ \\
\hline
\end{tabular}

The field of Biomedicine encompasses the following sub-fields: Biochemistry, Physiology, Biophysics, Immunology, Parasitology, Pharmacology and Microbiology. The area of Biology comprises 
the following sub-fields: Botany, Zoology, Genetics, Evolution and Ecology. The field of Astronomy was separated from the field of Physics since it has specific characteristics and a significant number of articles. Likewise, the field of surgery was considered separately from the field of Medicine. There are a great number of articles related to the comprehensive area of life sciences (Biomedicine, Medicine, Biology and Surgery) totaling 164 articles (66\%), which is a characteristic of the Brazilian scientific scenario where this field has historically prevailed. On the other hand, there are few articles on Engineering and Chemistry, two fields which are more closely linked to the field of technology. It is worth highlighting, however, that the lack of normalization of citation indexes affects fields such as Engineering, for example, where an article with 100 citations is more unusual than in Medicine. Likewise, there is no single article in Mathematics in the set studied. This will be further discussed.

\section{THE PHENOMENON OF INTERNATIONAL COLLABORATION}

Interinstitutional and international scientific collaboration has grown worldwide (Katz and Martin 1997) and particularly in Brazil (Meneghini 1996, Leta and Chaimovich 2002). This phenomenon is associated with multiple causes and is differently perceived in diverse scientific fields. Two of these causes are (i) the successful organization of networks to achieve results where multiple competencies and/or massive results are required and (ii) the high speed of communication over the web. It is clear that these two causes are interrelated.

The importance of international collaboration is plainly observed in the case of the most-cited Brazilian articles. Table II shows that $84.3 \%$ of the articles were written in international collaboration. Only 39 articles (15.7\%) had exclusively Brazilian authorship. According to a recent article (Hill 2001), it is worth noting that among the articles published in the ISI database of which authors had Brazilian affiliation, $37 \%$ were written in international collaboration (in 2001). When it comes to the most-cited articles, this percentage raises to 84.3. With stricter criterion, that is, when considering not ISI articles but highly cited ISI articles (from now on called HC-ISI), the share of international co-authorship becomes even stronger. The explanation to this is not simple and involves multiple factors. Actually, only now is the dynamics of scientific collaboration being studied in greater depth (Katz and Martin 1997). One of the factors to be considered in future research is who defines the collaboration most of the times - the developed or the developing country? If it is the developing country, it is necessary to verify whether there is a trend to choose strong groups in the developed countries to collaborate with. This factor would partly explain the phenomenon observed.

TABLE II

Articles by international collaboration and only Brazilian affiliation

\begin{tabular}{l|c|c}
\hline Affiliation & $\begin{array}{c}\text { Number of } \\
\text { articles }\end{array}$ & Percentage \\
\hline Collaboration & 209 & 84.3 \\
\hline Brazil & 39 & 15.7 \\
\hline Total & $\mathbf{2 4 8}$ & $\mathbf{1 0 0 . 0}$ \\
\hline
\end{tabular}

Although there is anecdotal evidence suggesting that US articles preferably cite US authors, which may interfere in the analysis given the overwhelming contribution of the US to the ISI database (King 2004), this distortion is not expected to bring about deep changes to the impact of publications.

The share of different countries which collaborate with Brazil is shown in Table III. The sum of the articles (580) and of the percentage values (232\%) surpasses the number of articles (248) and $100 \%$ due to the fact that the vast majority of papers written in collaboration result from multinational effort. To clarify the issue let us take an example: if each article written in international collaboration were written with a single country, the sum of the percentages should be the one shown in Table II (84.3\%). Again, it is interesting to note that in a similar list based on ISI articles in Brazil 
for the year 2001 (Hill 2001), the total percentage of collaboration reaches $108 \%$. That is, the multinational nature of international collaboration is more intense for HC-ISI than for ISI articles.

TABLE III

International collaboration, per country, in the most-cited articles.

\begin{tabular}{|c|c|c|}
\hline Country & $\begin{array}{c}\text { Number of } \\
\text { articles }\end{array}$ & Percentage \\
\hline United States & 145 & 58.0 \\
\hline France & 56 & 22.4 \\
\hline England & 47 & 18.8 \\
\hline Germany & 42 & 16.8 \\
\hline Italy & 37 & 14.8 \\
\hline The Netherlands & 24 & 9.6 \\
\hline Canada & 23 & 9.2 \\
\hline Switzerland & 21 & 8.4 \\
\hline Spain & 19 & 7.6 \\
\hline Australia & 17 & 6.8 \\
\hline Japan & 15 & 6.0 \\
\hline Argentina & 14 & 5.6 \\
\hline Mexico & 14 & 5.6 \\
\hline Sweden & 13 & 5.2 \\
\hline Russia & 11 & 4.4 \\
\hline Belgium & 11 & 4.4 \\
\hline China & 10 & 4.0 \\
\hline Israel & 10 & 4.0 \\
\hline Chile & 10 & 4.0 \\
\hline Portugal & 8 & 3.2 \\
\hline Denmark & 7 & 2.8 \\
\hline Colombia & 6 & 2.4 \\
\hline South Korea & 5 & 2.0 \\
\hline South Africa & 4 & 1.6 \\
\hline Uruguay & 4 & 1.6 \\
\hline Venezuela & 4 & 1.6 \\
\hline India & 3 & 1.2 \\
\hline Total & 580 & 232 \\
\hline
\end{tabular}

The sum exceeds 248 articles and $100 \%$, since most articles in collaboration involve more than one international affiliation.

Not surprisingly, the United States is the country that collaborates most with Brazilian authors. The other countries follow a sequence that is analogous to that for international collaboration of Bra- zilian ISI articles (Hill 2001). The percentages of collaboration for each one of the first four countries of Table III, as compared to the percentages of their publication of ISI articles, are 1.8, 4.0, 2.5 and 2.2 times higher, respectively. Therefore collaboration with these countries as regards HC-ISI articles greatly surpasses their representation in terms of ISI articles in the ISI-Thomson database.

Table III displays a modest participation of South American countries such as Argentina, Chile, Uruguay and Venezuela, which is also observed in the survey of ISI articles (Hill 2001). Apparently Brazil seeks international partnerships with developed countries more often than with neighboring countries. For comparison purposes, partnerships with closer countries are, in terms of percentage, one order of magnitude below relative to bilateral trade (Brasil 2004).

The little importance of the scientific interaction between Brazil and Argentina, Chile, Uruguay and Venezuela in terms of HC-ISI articles is even more evident if we consider that, of the 34 articles written in collaboration with these countries (Table III), only 6 were written exclusively in bilateral collaboration; in that, three were with Argentina and three with Uruguay (see more on that in Meneghini and Packer 2006). The remaining resulted from multinational collaboration where initiatives to bring together groups from Brazil and from these four countries individually were very likely not the major drivers of the collaboration.

The multinational character of the HC-ISI articles was measured for different fields (Table IV). In the fields of Biology, Chemistry and Biomedicine, the multinational character of collaboration is lower than in the fields of Astronomy, Physics, Medicine and Surgery (Engineering was not considered here because there were only three articles). In the fields of Medicine and Surgery, most of the articles included in our sample are articles dealing with investigation on medication, vaccines, treatment and surgical techniques. This type of work requires joint and comprehensive efforts on the part of many authors and countries through networks. 
TABLE IV

Multinationality of the most-cited articles.

\begin{tabular}{l|c}
\hline \multicolumn{1}{c|}{ Field } & $\begin{array}{c}\text { Countries/ } \\
\text { article }\end{array}$ \\
\hline Biomedicine & 2.7 \\
\hline Medicine & 5.3 \\
\hline Physics & 4.1 \\
\hline Biology & 2.6 \\
\hline Chemistry & 2.3 \\
\hline Surgery & 5.3 \\
\hline Astronomy & 6.6 \\
\hline Engineering & 2.3 \\
\hline Average & $\mathbf{3 . 8}$ \\
\hline
\end{tabular}

In these cases, it is expected that the results obtained through long-term evaluation have a strong impact which is translated in terms of citations. On the other hand, basic works on the effects of medication, development of drugs, vaccines, treatment and surgical techniques are published in articles where the participation of authors is more restricted. This type of work in general entails deeper insight and many such projects have given rise to Nobel prizes.

In the fields of Astronomy and Physics, the impact of work in large networks follows a different logic, and has more to do with the extensive collection of data needed by using extremely high-end and expensive equipment, such as large telescopes and accelerators. In these cases, due to the sharing of equipment through a time concession scheme, it is strategically convenient to build large multinational teams.

Without trying to compare the value of works developed by large networks to that of articles with more restricted authorship and multinationality, it is paramount to recognize that the participation of an author and/or a country in work produced within more extensive networks has a different meaning when compared to their participation in works with a lower level of collaboration. The former is an outcome of the emergence of an imperative of wideranging cooperation to obtain results in a reasonable timeframe. The latter derives from more individu- alistic and competitive work, more aligned with the traditional way of making science. In the first, the impact of a more shared article lessens the individual impact of each participant, whereas in the second, the individual impact is heightened. Therefore, although these two forms of making science are not mutually exclusive in any way - on the contrary they are today co-responsible for scientific and technological progress - the distinction between the individual impact of scientists on macro-operations and their impact on traditional organizations engaged in scientific production is worthy of consideration from a scientometric point of view. Moreover, citation indexes are increasingly used to measure scientific and academic performance.

In the fields of Biology, Biomedicine and Chemistry the macro-operations are not so significant, although the emergence of Genomics has affected Biology and Biomedicine. In these fields, the sequencing of genomes and the networks of structural genomics used to elucidate the atomic structure of proteins have proven the potential of networks. The field of Ecology has also benefited from the formation of networks. In Brazil, the genome projects formed multi-authorship rather than multinational networks. These projects are genuinely autochthonous, an aspect that should be emphasized because the success of networked projects depends not only on scientific elements but on the researcher ability to organize and manage them.

Multinationality is also reflected on the average number of article authors (Table V). The figures are relatively high as compared with articles produced two decades ago. Nonetheless there are marked differences between distinct fields. As a consequence of the lesser degree of multinationality in the fields of Biomedicine, Biology and Chemistry, the number of authors per article is smaller. In areas where there is greater multinationality such as Medicine, Surgery, Astronomy and Physics, the average number of authors is high, especially in the last two fields. One article in Physics generated 230 citations and has a total of 593 authors affiliated to 22 countries (Abreu et al. 1996). 
TABLE V

Mean number of authors per most-cited articles in different fields.

\begin{tabular}{l|c|c|c}
\hline \multicolumn{1}{c|}{ Field } & Authors & Articles & $\begin{array}{c}\text { Authors/ } \\
\text { articles }\end{array}$ \\
\hline Biomedicine & 610 & 67 & 9.1 \\
\hline Medicine & 763 & 51 & 14.9 \\
\hline Physics & 2534 & 41 & 61.8 \\
\hline Biology & 259 & 29 & 8.9 \\
\hline Chemistry & 114 & 23 & 5.0 \\
\hline Astronomy & 824 & 17 & 48.5 \\
\hline Surgery & 192 & 17 & 11.3 \\
\hline Engineering & 17 & 3 & 5.7 \\
\hline Total & $\mathbf{4 . 7 0 3}$ & $\mathbf{2 4 8}$ & $\mathbf{2 1 . 6}$ \\
\hline
\end{tabular}

\section{INSTITUTIONAL DISTRIBUTION OF THE MOST-CITED ARTICLES}

There are multiple interests in identifying institutions and regions that have a marked performance in science. In addition to encourage a healthy competition, of which fruits are not limited to exaltation, these indicators are important to establish scientific policies and to determine the success in their execution. In this sense, the most-cited articles are a powerful indicator (King 2004). Table VI shows, in a decreasing order, the institutions that gather the researchers with the most-cited articles. A total of 57 institutions appear in the affiliation of the mostcited articles, but the first eight are responsible for two thirds of these articles. This phenomenon of concentrating excellence occurs in other countries, in distinct scales regarding the number of HC-ISI articles.

The decreasing classification order of HC-ISI articles (this article) and of ISI articles (Abreu et al. 1996, FAPESP 2004) is similar but not equal, as shown in Figure 1. In this figure, the choice of a limited number of institutions was determined by the number of ISI articles for institutions available in results of surveys published elsewhere (FAPESP 2002, 2004).

There are institutions such as Universidade Federal do Rio Grande do Sul, Universidade
TABLE VI

Institutions with the most-cited articles.

\begin{tabular}{|c|c|}
\hline Institution & Articles \\
\hline Univ São Paulo, SP & 73 \\
\hline Univ Fed Rio de Janeiro & 26 \\
\hline Univ Est Campinas, UNICAMP, SP & 23 \\
\hline Univ Fed Rio Grande do Sul & 20 \\
\hline Univ Fed São Paulo, SP & 15 \\
\hline Inst Dante Pazzanezi, São Paulo & 11 \\
\hline Univ Fed Minas Gerais & 9 \\
\hline Ctro Bras Pesq Fisicas, Rio de Janeiro & 9 \\
\hline Inst Oswaldo Cruz, Rio de Janeiro & 6 \\
\hline Univ Est São Paulo & 5 \\
\hline Inst Nacional Pesq Amaz, Manaus, AM & 5 \\
\hline Lab Nacional Luz Síncrotron, Campinas, SP & 5 \\
\hline Inst Nacional Pesq Espac, SP & 5 \\
\hline Univ Fed Pernambuco & 3 \\
\hline Pont Univ Catol, Rio de Janeiro & 3 \\
\hline Observ Nacional, Rio de Janeiro & 3 \\
\hline Pont Univ Catol, Rio Grande do Sul & 3 \\
\hline Univ Fed Paraná & 3 \\
\hline Esc Evangelica Medicina, Curitiba, PR & 3 \\
\hline Univ Fed Pará & 3 \\
\hline Hospital Unicor, São Paulo & 2 \\
\hline Inst Ludwig Pesq Cancer, SP & 2 \\
\hline FIOCruz, BA & 2 \\
\hline Univ Nacional Brasília, DF & 2 \\
\hline Univ Fed Ceará & 2 \\
\hline Hosp Caron, Campo Gde do Sul, PR & 2 \\
\hline Univ Fed Bahia & 2 \\
\hline Univ Fed Sta Catarina, & 2 \\
\hline Hosp Sta Casa, Porto Alegre, RGS & 2 \\
\hline Hosp Sírio Libanês, São Paulo & 2 \\
\hline Univ Fed Mato Grosso Sul & 2 \\
\hline EMBRAPA, Belém, PA & 1 \\
\hline Labor Refer Salvador, BA & 1 \\
\hline Inst Adolfo Lutz, São Paulo & 1 \\
\hline Univ Fed Fluminense, Niteroi, RJ & 1 \\
\hline Univ Fed Goiás & 1 \\
\hline Hemocentro, São Paulo & 1 \\
\hline Inst Evandro Chagas, Belém, PA & 1 \\
\hline Fac Medic. Triângulo Mineiro, Uberaba, MG & 1 \\
\hline Univ Fed Juis de Fora, MG & 1 \\
\hline Univ Est Rio de Janeiro & 1 \\
\hline Secret Súde Pernambuco, Recife, PE & 1 \\
\hline
\end{tabular}


TABLE VI (continuation)

\begin{tabular}{l|c}
\hline Institution & Articles \\
\hline Univ Fed Alagoas & 1 \\
\hline Hosp Sta Casa, Curitiba, PR & 1 \\
\hline Hosp Alberto Eistein, São Paulo & 1 \\
\hline Univ Est Maringá, PR & 1 \\
\hline Univ Ribeirão Preto & 1 \\
\hline Inst Agronômico de Campinas, SP & 1 \\
\hline Inst Biológico, São Paulo & 1 \\
\hline Inst Butanta, São Paulo & 1 \\
\hline Univ Mogi das Cruzes, SP & 1 \\
\hline Univ Vale do Paraíba, SP & 1 \\
\hline Hosp Fed Pelotas, RG & 1 \\
\hline Univ Fed Paraíba & 1 \\
\hline Ctro Rene Rachou, Belo Horizonte, MG & 1 \\
\hline Inst Tecnologia Parana, Londrina, PR & 1 \\
\hline Ctro Citricultura, Cordeirópolis, SP & 1 \\
\hline Total & $\mathbf{2 8 4}$ \\
\hline
\end{tabular}

The sum exceeds 248 articles because of multi-institutional collaborations.

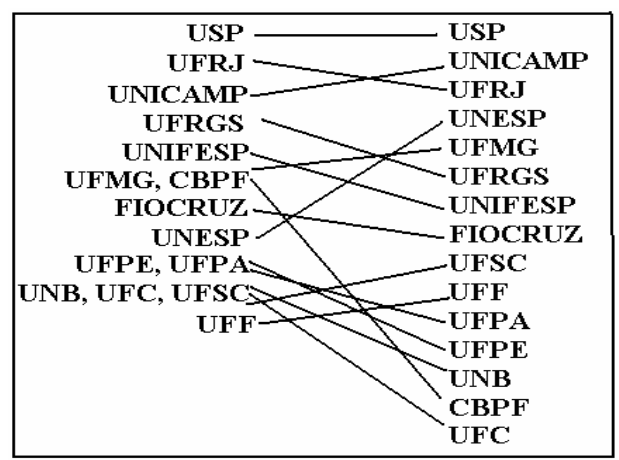

Fig. 1 - Comparing the ranking of HC-ISI articles (left) and ISI articles (right) of some important Brazilian institutions. The ranking of HC-ISI article results from this study, whereas the ISI articles are the Science, Technology and Innovation Indicators of the State of São Paulo, in 2002 and 2004 (9. 10).

Federal de São Paulo and Centro Brasileiro de Pesquisas Físicas with a high rate of HC-ISI articles as compared to ISI articles. Other institutions had relatively few articles with high a number of citations compared to the total number of ISI publications. As mentioned below, sometimes few groups are responsible for this unbalance. If these groups migrated from one institution to another, they could change its ranking in terms of HC-ISI.

In a recent research (Institute Of Higher Education 2004) conducted by a team from the Institute of Higher Education of Shanghai Jiao, from China, among the 500 universities classified as the best in the world, four are from Brazil - USP (153201), UFRJ (302-403), UNICAMP (302-403) and UNESP (402-502). The numbers in brackets are the ratings of these universities; from the hundredth position on, the authors chose to rate by ensemble instead of strictly ordinal.

One point worth mentioning is the presence, with a distinguished position in our ranking, of institutes, centers and thematic laboratories isolated from universities. They are small units known for performing high-level researches. Hence, it is not surprising that they are identified by the HC-ISI articles indicator. Seen by a different angle, this fact, per se, is a strong evidence of the correlation between the HC-ISI articles indicator and quality of scientific research.

Table VII demonstrates the division of universities into units, which are institutes, schools or departments, depending on the academic organization of each university. This division is important to show the research units in several sub-fields of knowledge. The isolated institutions displayed in Table VI were not repeated in Table VII. Two units from USP have their focuses on their sub-units Instituto de Química da USP with a department of fundamental chemistry and a biochemistry department, which are fields traditionally classified in distinct categories of natural sciences. The same applies to the Faculdade de Medicina da USP. In this case, the INCOR was highlighted, since it has a separate organizational structure and very specific research and service activities.

Several points are worth commenting. Of the fifteen units with high number of HC-ISI articles (five or more articles), ten are in the life sciences field. They comprise $47 \%$ of all HC-ISI articles in this large field (compare with Table I). It is also 
TABLE VII

University units with the most-cited articles.

\begin{tabular}{|c|c|}
\hline Institution & Articles \\
\hline Esc Paul Med UNIFESP & 15 \\
\hline Fac Med e Hosp Clin USP & 15 \\
\hline Dep Bioquímica Inst Quim USP & 10 \\
\hline Fac Cienc Médicas UNICAMP & 9 \\
\hline Inst Biofísica UFRJ & 9 \\
\hline Inst Física USP & 9 \\
\hline Inst Física UFRGS & 8 \\
\hline Fac Medicina Rib Preto USP & 7 \\
\hline Inst Biologia USP & 6 \\
\hline Inst Cien Biomédicas USP & 6 \\
\hline Inst Química UFRGS & 6 \\
\hline Inst Astron Geoc Cienc Atmosf USP & 6 \\
\hline Dep Imunol Bioquímica UFMG & 5 \\
\hline INCOR-FM USP & 5 \\
\hline Inst Física UFRJ & 5 \\
\hline Centro Ener Nuc Agric ESALQ USP & 4 \\
\hline Fac Filos Cien Letr Rib Preto USP & 4 \\
\hline Fac Med e Hosp Univ UFRJ & 4 \\
\hline Inst Biocienc Dep Bioquim UFRGS & 4 \\
\hline Inst Física UNICAMP & 4 \\
\hline Ctro Eng Genet Biol Molec UNICAMP & 3 \\
\hline Fac Odontol Bauru USP & 3 \\
\hline Inst Química UNICAMP & 3 \\
\hline Dep Bioquim Inst Biologia UNICAMP & 2 \\
\hline Dep Doenças Infecciosas FM UFBA & 2 \\
\hline Dep Ecologia UFPA & 2 \\
\hline Dep Genética Inst Biologia UNICAMP & 2 \\
\hline Dep Medicina UFCE & 2 \\
\hline Dep Qiom Fundam-Ist Quim USP & 2 \\
\hline Fac Engen Elet Comput UNICAMP & 2 \\
\hline Fac Med Vet Agric Jaboticabal UNESP & 2 \\
\hline Fac Med Vet Zoot USP & 2 \\
\hline Fac Med Zootec UNESP & 2 \\
\hline Fac Medicina UFRGS & 2 \\
\hline Hosp Clin Fac Med UFPR & 2 \\
\hline Inst Cienc Biomed UFRJ & 2 \\
\hline Inst Física S Carlos USP & 2 \\
\hline
\end{tabular}

TABLE VII (continuation)

\begin{tabular}{|c|c|}
\hline Institution & Articles \\
\hline Inst Matem Estat Comp Cient UNICAMP & 2 \\
\hline Inst Microbiol UFRJ & 2 \\
\hline Dep Física UFPE & 1 \\
\hline Dep Biol Celular UFSC & 1 \\
\hline Dep Cienc Farmaceut UNB & 1 \\
\hline Dep Comput Estat-UF Mato Grosso Sul & 1 \\
\hline Dep Ecologia UNB & 1 \\
\hline Dep Embriol Genet UFSC & 1 \\
\hline Dep Fis SJ Rio Preto UNIFESP & 1 \\
\hline Dep Física UFAL & 1 \\
\hline Dep Física UFMG & 1 \\
\hline Dep Física-UFPB & 1 \\
\hline Dep Física-Univ Est Maringá-PR & 1 \\
\hline Dep Genet UFPA & 1 \\
\hline Dep Genet UFRJ & 1 \\
\hline Dep Psiquiatria UFPR & 1 \\
\hline Dep Química UFCE & 1 \\
\hline Dep Química UFMG & 1 \\
\hline Dep Química UFPE & 1 \\
\hline Dept Física-Univ Fed Juiz Fora-MG & 1 \\
\hline Esc Politécnica USP & 1 \\
\hline Fac Cien Farmac Araraquara UNESP & 1 \\
\hline Fac Cien Farmac Rib Preto USP & 1 \\
\hline Fac Cien Letr Art Assis UNIFESP & 1 \\
\hline Fac Med Botucatu UNIFESP & 1 \\
\hline Fac Med e Hosp Clin UFMG & 1 \\
\hline Fac Med U Est Rio Janeiro & 1 \\
\hline Fac Medicina UFGO & 1 \\
\hline Fac Med-UF Pelotas-RGS & 1 \\
\hline Hosp Clin UFPE & 1 \\
\hline Hosp Procardiaco UFRJ & 1 \\
\hline Inst Bioc Dep Genet SJ Rio Preto UNESP & 1 \\
\hline Inst Física UFF & 1 \\
\hline Inst Química Araraquara UNESP & 1 \\
\hline Inst Química UFRJ & 1 \\
\hline Ist Química S Carlos USP & 1 \\
\hline Nuc Pesq Prod Nat UFRJ & 1 \\
\hline
\end{tabular}


important to note that among these 15 units, five are medical schools. Although most of the HC-ISI articles from these units refer to basic research in the medical field, there are many articles on Medicine and Surgery strict sense, as we will discuss ahead. This fact reveals a new scenario in Brazilian life sciences, that is, repercussion of research in the medical field.

In Physics, three units stood out - the Instituto de Física da USP, the Instituto de Física da UFRGS and the Instituto de Astronomia, Geociências e Ciências de Atmosfera da USP. In this case, the researches in large networks, with the use of large equipment, were important as mentioned above. This aspect is referred to in Meneghini and Packer 2006. It is also worth mentioning the Instituto de Química da UFRGS where, specifically, a chemistry group from the catalysis field has achieved significant impact.

\section{REGIONAL DISTRIBUTION OF THE MOST-CITED ARTICLES}

A compilation of HC-ISI articles in the highest ranked institutional-regional hierarchy by states, is shown in Table VIII. The predominance of the State of Sao Paulo $(51.5 \%)$ in HC-ISI articles is similar to that of ISI articles (47.3\%) (FAPESP 2002, 2004). The ranking differences in HC-ISI articles and ISI articles can be better visualized in Figure 2. As observed, although similar, it is possible to find differences between both rankings. Rio Grande do Sul, Paraná, Amazonas, Bahia and Mato Grosso do Sul have a number of HC-ISI articles proportionally higher than the production of ISI articles. In the case of Rio Grande do Sul, a small number of groups in the fields of Physics, Chemistry and Biochemistry make the difference.

As to the State of Amazonas, the Instituto Nacional de Pesquisa da Amazônia has some groups investigating issues related to the biology of the Amazon rainforest, focusing on the effects of deforestation, forest fires, gas exchange with the atmosphere, among others. Today, these issues are of international interest, and go beyond the aca- demic boundaries by finding editorial space not only in newspapers, but also in the best scientific journals. The State of Mato Grosso do Sul, on the other hand, stands out due to a computer science unit that contributed with proficiency in bioinformatics in genome network projects.

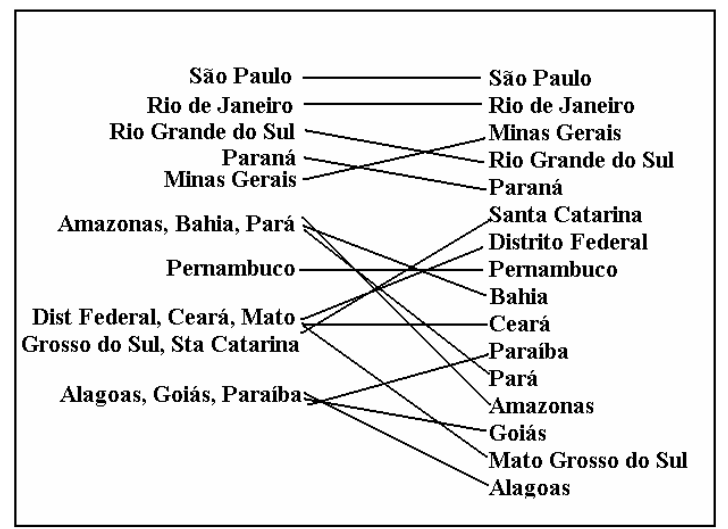

Fig. 2 - Comparing the ranking of HC-ISI articles (left) and ISI articles (right) of the Brazilian states. The ranking of HC-ISI articles results from this study, whereas the ISI articles are the Science, Technology and Innovation Indicators of the State of São Paulo, in 2002 and 2004 (9. 10).

\section{SCIENTIFIC JOURNALS THAT PUBLISHED THE MOST-CITED ARTICLES}

Table IX shows the journals that published two or more HC-ISI articles. There are 34 journals that published 154 articles (62\%). The remaining 94 articles were published by 94 journals not shown in Table IX. Among these 34 journals, none is a Brazilian journal listed in the Thomson ISI database (currently with 20 journals). However, a Brazilian journal published an article with 196 citations (Aksnes and Sivertsen 2004).

It is not surprising to see that the journals that most published HC-ISI articles are those recognized as having the highest impact factors - Nature (all versions) and Science, among the multidiscipline journals, Lancet and New England Journal of Medicine, in the fields of Medicine and Surgery, Physical Review Letters and Physical Review, in Physics, and Astrophysical Journal, in the field of 
TABLE VIII

Brazilian states with highly-cited ISI articles (HC-ISI) and total ISI articles.

\begin{tabular}{l|c|c|c|c}
\hline \multicolumn{1}{c|}{ State } & $\begin{array}{c}\text { HC-ISI } \\
\text { articles }\end{array}$ & $\begin{array}{c}\text { \% HC-ISI } \\
\text { articles }\end{array}$ & $\begin{array}{c}\text { ISI articles } \\
98-02\end{array}$ & $\begin{array}{c}\text { \% ISI articles } \\
98-02\end{array}$ \\
\hline São Paulo & 135 & 50.8 & 33,499 & 47.3 \\
\hline Rio de Janeiro & 49 & 18.4 & 12,270 & 17.3 \\
\hline Rio Grande do Sul & 26 & 9.8 & 5,067 & 7.2 \\
\hline Paraná & 14 & 5.3 & 3,161 & 4.5 \\
\hline Minas Gerais & 12 & 4.5 & 6,138 & 8.7 \\
\hline Amazonas & 5 & 1.9 & 568 & 0.8 \\
\hline Bahia & 5 & 1.9 & 1,163 & 1.6 \\
\hline Pará & 5 & 1.9 & 680 & 1.0 \\
\hline Pernambuco & 4 & 1.5 & 1,667 & 2.4 \\
\hline Distrito Federal & 2 & 0.8 & 1,725 & 2.4 \\
\hline Ceará & 2 & 0.8 & 1,130 & 1.6 \\
\hline Mato Grosso do Sul & 2 & 0.8 & 364 & 0.5 \\
\hline Santa Catarina & 2 & 0.8 & 1,883 & 2.7 \\
\hline Alagoas & 1 & 0.4 & 202 & 0.3 \\
\hline Goiás & 1 & 0.4 & 561 & 0.8 \\
\hline Paraíba & 1 & 0.4 & 723 & 1.0 \\
\hline Total & $\mathbf{2 6 6}$ & $\mathbf{1 0 0 . 0}$ & $\mathbf{7 0 , 8 0 1}$ & $\mathbf{1 0 0 . 0}$ \\
\hline
\end{tabular}

Data of HC-ISI articles were obtained from this study. ISI article data from 1998-2002 were collected in another source $(9,10)$. The sum of 266 exceeds 248 because there are articles in interinstitutional collaboration included more than once (14 articles).

Astronomy. As to Biomedicine, Chemistry and Biology there was no concentration in a small number of journals but a tendency of publishing in journals related to sub-fields.

\section{FINAL REMARKS}

The present radiography of the most-cited papers in a recent period of ten years in Brazil (1994-2003) helps to understand more deeply the trends of science in this country. Deliberately, the sample that has been studied is a small one (articles with more than 100 citations in the period) consisting of 248 articles which correspond to $0.23 \%$ of the Brazilian production registered in the webofscience database. The total number of citations to these 248 articles was 46,142 (not shown). The methodology employed is analogous to that of a recent study on the output of science in a group of selected countries (King 2004) In this article, which covered the same timeframe as the present study, the total number of references to papers with Brazilian affiliation averaged $\sim 37$ thousands per year. Therefore the total number of citations to Brazilian paper in 19942003 is approximately 379,000 . Thus, one is dealing with $0.23 \%$ of the $1994-2003$ Brazilian articles that were accountable for $12 \%$ of the total citations received in this period. Recent studies have addressed the important contribution that a few highly cited papers may have to the average citation rates of a country (Aksnes and Sivertsen 2004).

The articles of the most-cited papers are not scattered in several senses. They are very much centered in the area of biomedical sciences $(67 \%)$, a circumstance explained by the history of the growth of science in Brazil (Schwartzman 1979). 
TABLE IX

Journals publishing the most-cited articles (two or more articles).

\begin{tabular}{l|c}
\hline Journal & Articles \\
\hline Nature & 18 \\
\hline Science & 14 \\
\hline Lancet & 12 \\
\hline Physical Review Letters & 12 \\
\hline Astrophysical Journal & 9 \\
\hline Physical Review & 9 \\
\hline New England Journal of Medicine & 8 \\
\hline Circulation & 6 \\
\hline Astronomy \& Astrophysics & 4 \\
\hline Human Molecular Genetics & 4 \\
\hline JAMA & 4 \\
\hline Journal of Clinical Microbiology & 4 \\
\hline Free Radical Biology and Medicine & 3 \\
\hline Journal of Immunology & 3 \\
\hline Journal of the American College of Cardiology & 3 \\
\hline Journal of Virology & 3 \\
\hline Pharmacology Biochemistry and Behavior & 3 \\
\hline Thrombosis and Haemostasis & 3 \\
\hline Annals of Thoracic Surgery & 2 \\
\hline Applied Physics Letters & 2 \\
\hline Blood & 2 \\
\hline Dental Materials & 2 \\
\hline European Journal of Neuroscience & 2 \\
\hline FEBS Letters & 2 \\
\hline IEEE Transactions & 2 \\
\hline Infection and Immunity & 2 \\
\hline Journal of Pharmacology and Experimental Therapeutics & 2 \\
\hline Journal of the National Cancer Institute & 2 \\
\hline Neurobiology of Learning and Memory & 2 \\
\hline Neurology & 2 \\
\hline Nuclear Instruments and Methods in Physics & 2 \\
\hline Peritoneal Dialysis International & 2 \\
\hline Proceedings of the National Academy of Sciences of the USA & 2 \\
\hline Total & 2 \\
\hline
\end{tabular}

They are very much concentrated in three states: São Paulo, Rio de Janeiro and Rio Grande do Sul (79\%) and they pinpoint groups of excellence in a limited number of topics (47\%, see Meneghini and Packer 2006). Moreover, they show a high dependence on international collaboration, in most cases multinational, to achieve the status of most-cited (84\%), a percentage well above that of average papers in ISI journals for Brazilian articles $(37 \%, 7)$. The origin of these collaborations is an interesting subject to be investigated. It requires a relatively extensive survey and in principle the question that 
could be addressed is where did the initiative originate from, if from the Brazilian group or the collaborator counterpart. The fact that the collaboration of international groups was more demanded for the production of the most-cited articles than for the average articles may have distinct explanations in different cases. Among others, search by local groups for such collaborations aimed at prestigious international groups, the opposite situation when these international groups were looking for subjects and/or facilities not within reach in their countries or, more prosaic, the explanation is simply statistical and lies on the socio-psychological reason that developed country authors are more citationtargeted.

The multinational character of the majority of papers is correlated with a high number of authors per article (average of 21.6). However, a marked difference is observed in these figures when one examines distinct areas. Physics (61.8), astronomy (48.5) and medicine (14.9) present the highest number of authors per article, basically due to the mode of operation to obtain data in experiments in these areas, through the use of high-cost equipment (telescopes in astronomy and accelerators of sub-atomic particles in physics) or extensive information collection in multicentric studies in medicine. This issue is addressed at length in Meneghini and Packer 2006.

The network frame of many of the most-cited articles is also patent. Large networks are common in physics, astronomy and medicine for the reasons explained above. Its use has been extended to the area of genomics where a concentrated and coordinated effort is required to sequence a whole genome. The own fact of making available a richness of information in these network efforts tends to bestow a number of considerable citations to these articles and several of the most-cited articles in the present study belongs to this category. From a dualistic viewpoint one may see network efforts to focus into less conceptual problems than traditional less numerous authorship articles do. This has posed a scientometrics difficulty in the straightforward use of the number of citations of an author for the pur- pose of assessing scientific quality. Recently, an ingenious indicator has been put forward to circumvent this problem (Hirsch 2005).

The approach of using the most-cited articles to map thematic groups of excellence has produced interesting results (ensuing article). To our knowledge this is the first time that this attempt has been made at the level of a nation. Although a survey on the scientific community perception of the excellence of the sub-areas mapped has not been carried out, in informal exchange of opinions it has come to our attention that in most of the cases, but not in all, the results confirmed previous impressions. The most-cited indicator seems to constitute a quantitative assessment to be taken into account in scientific policy.

\section{ACKNOWLEDGMENTS}

The authors thank Maria Elisa Rangel Braga, Rosely Fátima Pellizzon and their team for the valuable help.

\section{RESUMO}

Foram identificados os artigos com um mínimo de 100 citações na literatura científica e com ao menos uma filiação brasileira, segundo a base bibliométrica Thomsom ISI, no período de 10 anos entre 1994 e 2003. Dos 109.916 artigos com filiação brasileira neste período, 248 apresentaram 100 ou mais citações, ou seja, 0,23\% do total. Este levantamento foi feito primordialmente para identificar núcleos temáticos de excelência em pesquisa que tiveram maior impacto na literatura internacional (veja Meneghini and Packer 2006). As distribuições regional e institucional das afiliações desses artigos mais citados seguem aproximadamente aquela do total de artigos brasileiros na base ISI. No entanto, notam-se alguns desvios significativos derivados de grupos destacados quanto à publicação de trabalhos muito citados. Ficou patente que o papel das organizações em rede de pesquisa e as colaborações internacionais tiveram uma grande influência no impacto desses artigos, mas com distinta amplitude nas diversas áreas.

Palavras-chave: bibliometria, editoração/estatística e 
dados numéricos, serviços de informação, armazenamento e recuperação da informação, ciência, autoria, publicações periódicas/normas, cienciometria, fator de impacto, colaboração científica, rede científica.

\section{REFERENCES}

AbreU P ET AL. 1996. Performance of the DELPHI detector. Nucl Instrum Methods Phys Res Section A 378: $57-100$.

Aksnes DW And Sivertsen G. 2004. The effect of highly cited papers on national citation indicators. Scientometrics 59: 213-224.

BRASIL 2004. Ministério do Desenvolvimento Indústria e Comércio Exterior. Balança comercial brasileira em Dezembro de 2004.

http://www.abracex.com.br/abra/arq_esp_associado/ NotaImprensa_2004dezembro_FINAL1_.doc

FAPESP. 2002. Indicadores de Ciência, Tecnologia e Inovação em São Paulo. São Paulo, SP, Brasil.

FAPESP. 2004. Indicadores de Ciência, Tecnologia e Inovação em São Paulo. São Paulo, SP, Brasil.

Garfield EM AND SMall H. 1978. Citation Data as science indicators. In: ELKANA Y, LEDERBER J, Merton RK, Thackray A And ZUCKERMAN $\mathrm{H}$ (Eds), Toward a metric of science: the advent of science indicators. New York: J Wiley \& Sons, p. 179-207.

GARFIEld E AND Welluams-Dorof A. 1992. Of Noble class: a citation perspective on high impact research authors. Theoretical Med 13: 117-135.

HILl DL. 2001. Latin America shows rapid rise in science \& engineering articles. National Science Foundation. http://www.nsf.gov/sbe/srs/infbrief/nsf04336/ start.htm-
HIRSCH JE. 2005. An index to quantify an individual's scientific research output. Proc Natl Acad Sci USA 46: 16569-16572.

InSTITUTE OF Higher EdUCATION. 2004. Academic Ranking of World Universities Shanghai: Jiao Tong University. http://ed.sjtu.edu.cn/ranking.htm

KATZ DA AND MARTIN BR. 1997. What is Research Collaboration. Res Policy 62: 1-18.

KING DA. 2004. The scientific impact of nations. Nature 430: 311-316.

http://www.nature.com/nature/journal/v430/n6997/ full/430311a.html

Leta J And Chaimovich H. 2002. Recognition and international collaboration: the Brazilian case. Scientometrics 53: 325-335.

http://www.springerlink.com.w10080.dotlib.com.br/ media/d86tgdpwwn5yqvb7tpq0/contributions/5/h/4/ b/5h4blf60q82kj83v.pdf

Meneghini R. 1996. The key role of collaborative work in the growth of the Brazilian science in the last ten years. Scientometrics 35: 367-373.

http://www.springerlink.com.w10080.dotlib.com.br/ (ncg1sly0gghdhd552xh45bva)/app/home/ contribution.asp?referrer=parent\&backto= searcharticlesresults, 2,2

Meneghini R And Packer AL. 2006. Articles with authors affiliated in Brazilian institutions published from 1994 to 2003 with 1 or more citations: II - Identification of thematic nuclei excellence in Brazilian science. An Acad Bras Cienc 78: 855-883.

SCHWARTZMAN S. 1979. Formação da comunidade científica no Brasil. Editora Nacional, São Paulo, SP, Brasil. 